\title{
OBSTETRICS AND GYNECOLOGY
}

UDC 618.14-007.17+618.19-007.17:612.018.2

\section{Specifics of Hormonal Status in Combined Dishormonal Pathology of the Uterus and Mammary Glands in Reproductive Age}

\author{
M. S. Shelygin, N.S. Guziy, V.S. Kaplitskaya \\ North-Western State Medical University named after I. I. Mechnikov, \\ 41, ul. Kirochnaya, St. Petersburg, 191015, Russian Federation
}

For citation: Shelygin M.S., Guziy N.S., Kaplitskaya V.S. Specifics of Hormonal Status in Combined Dishormonal Pathology of the Uterus and Mammary Glands in Reproductive Age. Vestnik of Saint Petersburg University. Medicine, 2019, vol. 14, issue 2, pp. 123-131.

https://doi.org/10.21638/spbu11.2019.204

The combined dyshormonal pathology of the uterus and mammary glands represents a great danger to the health of a woman, as well as impairs the quality of life, reduces the reproductive capacity of a woman and leads to premature loss of reproductive function. Steroid hormones play a large role in the regulation of proliferative changes in the uterus and mammary glands. Regulation of target organs, uterus and mammary glands, due to the presence of common mechanisms associated with the presence of the receptor apparatus in the tissues of these organs to sex hormones. The general links of pathogenesis and the high frequency of combined pathology of the uterus and mammary glands are of interest to study not only isolated forms of proliferation, but also the development of a unified systematic approach to the study of this pathology. In recent times, there are opposing views on the role of hormonal dysfunction as a factor in proliferative processes. The management tactics of patients with pathological changes in the mammary gland in various gynecological diseases is an assessment of endocrine status, normalization of hormonal and metabolic disorders, especially when progesterone and cortisol are excreted, testosterone levels are increased, and hyperprolactinemia is affected. Special attention should be paid to patients with menstrual disorders, reproductive health disorders. We believe that the problem of the hyperproliferative processes of the uterus and mammary glands should not be considered only from the perspective of gynecological or mammological practice. This pathology is polymorphic and should have broad interdisciplinary connections with such disciplines as oncology, endocrinology, gastroenterology, psychiatry, therapy, pathomorphology, histology, obstetrics and gynecology. Only by studying all possible links of etiopathogenesis, by combining interdisciplinary communication, it is possible to effectively fight for the quality of patients with a combined pathology of the uterus and mammary glands. Family planning, prevention of

(c) Санкт-Петербургский государственный университет, 2019 
unplanned pregnancy, timely implementation of maternity, prevention of miscarriage, the use of modern contraceptives, support for breastfeeding is also of high importance for the prevention of disorders and the preservation, extension of reproductive capabilities, and the prevention of combined dyshormonal pathology of the uterus and breast.

Keywords: hormonal status, mammary glands hyperplastic processes, endometrial hyperplasia, uterine fibroids, fibrocystic disease of the breast, ovarian dysfunction, especially steroidogenesis, women of reproductive age, hormonal dysfunction, hyperprolactinemia, proliferative breast disease, anovulation, gipoestrogeniya, hyperandrogenism, menstrual cycle.

\section{Introduction}

Some aspects of the pathogenesis of uterine fibroids and fibrocystic disease of the breast still remain an important issue for research by modern Russian and foreign authors $[1 ; 2]$. At the same time, significant progress in molecular genetics and biology makes it possible to identify genetic factors and initial molecular defects leading to the development of proliferative changes in the uterus and mammary glands. It is known that benign diseases of the mammary glands in gynecological patients are most often found in cases of uterine fibroids, which is associated with the common pathogenesis and morphological processes occurring in the target organs: uterus and mammary glands [3].

The menstrual function and the processes occurring in the mammary glands are under the common neuroendocrine control of the hypothalamic-pituitary-ovarian and adrenal systems, as well as under the effect of the action of other endocrine glands and growth factors [3; 4]. Benign breast diseases are observed in 20-25\% of women under the age of $30,60 \%$ or more aged 40 and older, and these diseases are the background for the development of breast cancer [3].

It is proved that breast cancer occurs 3-5 times more often against the background of fibrocystic disease of the breast and 25-30 times more often in the presence of proliferative processes, and it is the main component in the structure of cancer incidence [5]. According to the definition of the WHO, fibrocystic disease of the breast is a disease with an abnormal ratio of epithelial and connective tissue components and a wide spectrum of proliferative and regressive changes in the breast tissue [6]. During a woman's reproductive years, her mammary gland often undergo proliferative and regressive changes in the epithelial and supporting tissues, which is associated with the phases of the menstrual cycle and, therefore, with different levels of sex hormones.

Improper regulation of these processes often leads to structural changes, which can be manifested in the form of diffuse and diffuse-nodal changes. The most common of them is fibrocystic disease of the breast [7].

It is known that $97.8 \%$ of women of reproductive age with neuroendocrine gynecological diseases are found to have pathological alterations of mammary glands [3]. It is noted that in women with oligomenorrhea, breast lesions occur in $64.5 \%$ of cases, and hyperplastic processes are observed 2 times more often than in the endometrium.

In patients with gynecological diseases accompanied by dysfunctional uterine bleeding, concomitant diseases of mammary glands are found in $57.6 \%$ of cases; in secondary amenorrhea, these are found in $43.6 \%$ of the patients, and among women with polycystic ovary syndrome, in $25 \%$ of cases. The data obtained made it possible to develop a concept of the common pathogenesis of the mechanisms of the development of hor- 
mone-dependent hyperplastic diseases of female genital organs and mammary glands. Uterine fibroids are still one of the most frequent gynecological diseases. The incidence of this pathology reaches $20-30 \%$ among women of reproductive age, and according to autopsy data, its prevalence is about $50-77 \%$ [8; 9]. About $80 \%$ of women in the age of perimenopause have a high risk of tumors. However, in the recent years, a trend for the younger onset of disease has been observed: often uterine fibroids are found in 20-yearold patients, especially since the preclinical stage lasts on an average for 8-10 years, and preventive examinations result in the discovery of the tumor in $1-5 \%$ of women, and small myomatous nodes are found at ultrasound examination in $20 \%$ of women [10].

Risk factors for uterine fibroids are ethnicity, parity (the relative risk of uterine fibroids is reduced with the increase of the number of deliveries in pregnancies reaching viable gestational age and increases in women who had artificial abortions), being overweight, hereditary predisposition, concomitant inflammatory diseases of the genitals, endometriosis, intrauterine interventions [11].

Uterine fibroids have an adverse effect on the woman's reproductive health. A frequent complication of uterine fibroids is infertility. In recent years, there has been a clear increase in the frequency of the combination of uterine fibroids and pregnancy (from 0.5 to $6 \%$ ). In most cases, pregnancy and childbirth in women with uterine fibroids are accompanied by frequent complications: threatening miscarriage, fetoplacental insufficiency, abnormal labor, hypotonic bleedings, subinvolution of the uterus, etc.

Often, uterine fibroids are combined with other hyperplastic processes of the reproductive organs and mammary glands (endometriosis, endometrial hyperplasia, background diseases of the cervix and various forms of fibrocystic disease of the breast).

Particularly important among the risk factors for breast cancer are proliferative diseases of the mammary glands, which are grouped by WHO experts under the term of fibrocystic disease of the breast.

In this regard, the College of American Pathologists recommends to divide women with fibrocystic disease of the breast into three categories [12; 13]:

- non-proliferative fibrocystic disease or the disease with a light intraductal epithelial proliferation. The risk of the development of infiltrating cancer is not increased and is at the same level as the risk in the general population;

- fibrocystic disease with moderate intraductal epithelial proliferation. The risk of infiltrating breast cancer development is 1.5-2 times higher than the risk for the general population;

- fibrocystic disease with atypical intraductal proliferation. The risk of infiltrating breast cancer is 5 times higher compared to the risk for the general population. The risk of breast cancer in patients with epithelial proliferation in the lumen of the glandular cavities is 14 times higher than in patients without such proliferation [14]. Histological examination revealed a combination of proliferative forms of fibrocystic disease of the breast and minimal breast cancer in $55-67 \%$ of cases $[15 ; 16]$. Moreover, current data indicate a morphogenetic relationship between proliferative forms of fibrocystic disease of the breast and minimal breast cancer. Pechoux C., in the paper on the possible relationship between fibrocystic disease of the breast and breast cancer, stressed that sclerocystic mastitis (cystic disease of breast, Reclus' disease, Schimmelbusch's disease) refers to diseases that tend to malignize under certain conditions [17]. There is an opposite opinion, according 
to which fibrocystic disease of the breast is a "functional0 $\Phi$ estrogen-dependent state, which is capable of spontaneous regression in postmenopause. According to T. Gudjonsson, cystic changes in the mammary gland, in cases of individual cysts, regress in the first year after the termination of menses in $50 \%$ of cases, and in the second year, in $73 \%$ of cases. However, the author showed that in postmenopausal period of 5 years or more, positive dynamics is observed only in $12 \%$ of patients with fibrocystic disease of the breast [18].

It is known that pathological conditions of the gastrointestinal tract which are associated not only with liver function disorders but also with intestinal function disorder, lead to reabsorption of steroid hormones. This results in the development of estrogen-dependent diseases such as fibrocystic disease of the breast and breast cancer. These patients are recommended to undergo treatment and correction of gastrointestinal disorders by a gastroenterologist, to take adequate amount of fluids, up to 2 liters per day, and increased consumption of foods containing fiber [19].

The therapy method which must be considered the most nosotropic, taking into account the hormonal regulation of the mammary gland, is the use of hormonal agents. Oncologists, mammologists, gynecologists, and surgeons have accumulated data on the possibility of effective use of various hormonal methods of treatment of benign pathology of the mammary glands [6]. It should be noted that it is currently believed that a decisive role in the development of mammary glands diseases belongs to progesterone-deficient conditions, in which excess estrogen causes proliferation of breast tissue and the receptor apparatus disorder.

Clinical practice confirms that the majority of patients with gynecological diseases, especially with dishormonal disorders, also have some mammary gland diseases. At the same time, the greatest risk of severe pathology of the mammary glands exists for women with hyperplastic processes of the genitals. The structure of breast pathology in patients with neuroendocrine genital pathology is as follows [20]:

1) hyperplastic diseases: $65.4 \%$;

2) premature involutive changes: $32.5 \%$;

3) nodal proliferative processes: $6.5 \%$.

The literature data indicate the relevance and necessity of studying the condition of the mammary gland, and a special emphasis must be made on the administration of the appropriate pathogenetically substantiated therapy of both gynecological diseases and breast pathology.

Goal of research: to study and evaluate the role of changes in the hypothalamicpituitary-ovarian system, taking into account the clinical features of patients with benign breast diseases, proliferative fibrocystic disease of the breast with hyperplastic processes of the uterus in the background, including the endometrium.

\section{Materials and methods}

To reach the stated goal, 350 women underwent medical tests and examinations. Three representative clinical groups of patients were formed. The first (1) group included 150 patients with benign diseases of the mammary glands against the background of hyperplastic processes of the uterus, including the endometrium, the second (2) group 
consisted of 50 patients with proliferative fibrocystic disease of the breast, and the third (3) (control) group included 150 patients with hyperplastic processes of the uterus not accompanied by breast diseases.

The patients were selected for the group based on a copy-pair principle. The examined patients were from 20 to 40 years old. The past medical history of the examined women was studied according to the questionnaire we had developed. Special attention was paid to heredity, gynecological, mammal and oncological diseases in close relatives, as well as to extragenital diseases in the patient's medical background. Also, copies of information were made from the primary medical records of the women, which made it possible to adjust the data of the survey.

Measurements were taken of the women's height, weight, waist, hips, and the body mass index and the waist-to-hips ratio were calculated. The severity and nature of endometrial pathology were determined with the use of transvaginal ultrasound, aspiration biopsy of the endometrium, hysteroscopy with separate diagnostic curettage of the cervical canal and uterine mucosa, and cervical biopsy followed by histological examination according to the generally accepted technique. All the women were examined by a therapist and consulted by a mammologist.

For examination of the mammary glands the following diagnostic methods were used: examination and palpation by conventional methods, mammography, ultrasound, morphological examination of biopsies.

The functional status of hypothalamic-pituitary-ovarian system and the adrenal function in the blood were studied with the use of functional diagnostics (temperature test, the cervical pupil sign, the crystallization of mucus). The content of hormones in the blood (FSH - follicle stimulating hormone, LH - luteinizing, PRL - luteotropic (prolactin) hormones of the pituitary gland, E2 - estradiol, PG-progesterone) was determined by enzyme immunoassay method with the use of the generally accepted technique. The levels of 17-ketosteroids and 17 - oxycorticosteroids were determined according to generally accepted recommendations.

The criteria for exclusion from the study were a body mass index of more than 30 , the absence of independent menstruation, diabetes and hormonal therapy administration.

The statistical processing of the results was performed with the use of EXIL20G0 software. The significance of the differences was assessed with the use of Student's ttest, Pearson's correlation coefficient and $\mathrm{x}^{2}$ criterion. For all types of analysis, statistically significant difference was $\mathrm{p}<0.05$.

\section{Findings}

Our findings show that patients with proliferative fibrocystic disease of the breast (group 2) had the highest concentration of luteinizing hormone (1 group: $6.02 \pm 0.13 \mathrm{nmol} / \mathrm{l}, 2$ group: $13.06 \pm 0.67 \mathrm{nmol} / \mathrm{l}$, and 3 group: $5.82 \pm 0.54 \mathrm{nmol} / \mathrm{l}$ ) and follicle stimulating hormone (1 group: $3.86 \pm 0.97 \mathrm{nmol} / \mathrm{l}, 2$ group: $16.85 \pm 3.21 \mathrm{nmol} / \mathrm{l}$, and 3 group: $4.10 \pm 0.16 \mathrm{nmol} / \mathrm{l}$ ) and reduced concentration of estradiol (1 group: $225.73 \pm 22.34 \mathrm{pg} / \mathrm{ml}, 2$ group: $66.94 \pm 16.41 \mathrm{pg} / \mathrm{ml}$, and 3 group: $196.57 \pm 22.93 \mathrm{pg} / \mathrm{ml}$ ) and progesterone (1 group: $8.07 \pm 0.35 \mathrm{nmol} / \mathrm{l}, 2$ group: $5.11 \pm 0.7 \mathrm{nmol} / \mathrm{l}$, and 3 group: $16.48 \pm 2.21 \mathrm{nmol} / \mathrm{l})$. Moreover, the highest testosterone content was found in patients of group $1(1.05 \pm 0.09 \mathrm{ng} / \mathrm{ml}, \mathrm{p}<0.05$ compared to groups 2 and 3$)$ (Table 1$)$. 
Table 1. Endocrine status specifics

\begin{tabular}{|l|c|c|c|}
\hline \multirow{2}{*}{\multicolumn{1}{|c|}{ Characteristics }} & \multicolumn{3}{c|}{ Groups of patients } \\
\cline { 2 - 4 } & $\mathbf{1} \mathbf{n}=\mathbf{1 5 0}$ & $\mathbf{2 n = 5 0}$ & $\mathbf{3} \mathbf{n}=\mathbf{1 5 0}$ \\
\hline Luteinizing hormone $(\mathrm{nmol} / \mathrm{l})$ & 6.020 .13 & $13.06 \pm 0.67^{\star}$ & $5.20 \pm 0.54$ \\
\hline $\begin{array}{l}\text { Follicle stimulating hormone } \\
(\mathrm{nmol} / \mathrm{l})\end{array}$ & $3.85 \pm 0.09$ & $16.85 \pm 3.22^{\star *}$ & $4.10 \pm 0.16$ \\
\hline Estradiol $(\mathrm{pg} / \mathrm{ml})$ & $225.73 \pm 22.37$ & $86.94 \pm 16.41^{\star *}$ & $196.57 \pm 22.93$ \\
\hline Progesterone $(\mathrm{nmol} / \mathrm{l})$ & $8.07 \pm 0.35^{*}$ & $5.11 \pm 0.76^{\star *}$ & $16.48 \pm 2.20$ \\
\hline Prolactin $(\mathrm{ng} / \mathrm{ml})$ & $8.8 \pm 0.131$ & $7.42 \pm 0.48$ & $7.35 \pm 0.93$ \\
\hline Cortisol $(\mathrm{nmol} / \mathrm{l})$ & $457.31 \pm 32.11$ & $419.93 \pm 15.49$ & $432.32 \pm 42.24$ \\
\hline Testosterone $(\mathrm{ng} / \mathrm{ml})$ & $1.05 \pm 0.09^{*}$ & $0.69 \pm 0.06$ & $0.79 \pm 0.13$ \\
\hline
\end{tabular}

Preliability relative to group $3^{*}<0.05$ and ${ }^{*}<0.01$.

The specifics of menstrual dysfunction in the women examined were as follows: patients with a combination of hyperplastic processes of the mammary glands and uterus had ovulatory $(33.3 \%)$ or anovulatory $(46.7 \%)$ menstrual cycle or luteal phase insufficiency $(20.0 \%)$. Patients with proliferative fibrocystic disease of the breast had anovulatory $(74.0 \%)$ menstrual cycles or luteal phase insufficiency $(26.0 \%)$ (Table 2).

Table 2. The specifics of the menstrual dysfunction (\%)

\begin{tabular}{|l|c|c|c|}
\hline & Group 1 & Group 2 & Group 3 \\
\hline Regular menstrual cycle & 73.3 & - & 33.3 \\
\hline Luteal phase insufficiency & 26.7 & 26 & 20 \\
\hline Anovulatory cycle & - & 74 & 46.7 \\
\hline
\end{tabular}

Women with regular ovulatory menstrual cycle typically had progesterone excretion within the acceptable range, close to the lower limit, and high testosterone content (Table 3).

Table 3. The specifics of endocrinological status in patients with a regular menstrual cycle

\begin{tabular}{|l|c|c|}
\hline \multirow{2}{*}{\multicolumn{1}{|c|}{ Characteristics }} & \multicolumn{2}{|c|}{ Groups of patients } \\
\cline { 2 - 3 } & $\mathbf{1} \mathbf{n}=\mathbf{5 0}$ & $\mathbf{3 n = 1 1 0}$ \\
\hline LH $(\mathrm{nmol} / \mathrm{l})$ & $4.65 \pm 0.53^{*}$ & $6.99 \pm 0.28$ \\
\hline FSH $(\mathrm{nmol} / \mathrm{l})$ & $3.32 \pm 0.40^{*}$ & $4.10 \pm 0.23$ \\
\hline LH/FSH & $1.22 \pm 0.12^{*}$ & $1.41 \pm 0.08$ \\
\hline Estradiol $(\mathrm{pg} / \mathrm{ml})$ & $224.57 \pm 23.34$ & $234.90 \pm 22.43$ \\
\hline
\end{tabular}


Ending of Table 3

\begin{tabular}{|l|c|c|}
\hline \multirow{2}{*}{ Characteristics } & \multicolumn{2}{|c|}{ Groups of patients } \\
\cline { 2 - 3 } & $\mathbf{1} \mathbf{n}=\mathbf{5 0}$ & $\mathbf{3} \mathbf{n}=\mathbf{1 1 0}$ \\
\hline Prolactin $(\mathrm{ng} / \mathrm{ml})$ & $7.53 \pm 0.90$ & $9.41 \pm 0.99$ \\
\hline Cortisol $(\mathrm{nmol} / \mathrm{l})$ & $488.30 \pm 51.71^{\star}$ & $728.67 \pm 64.15$ \\
\hline Testosterone $(\mathrm{ng} / \mathrm{ml})$ & $0.94 \pm 0.14^{\star}$ & $0.56 \pm 0.06$ \\
\hline
\end{tabular}

Preliability relative to group $3^{\star}<0.05$ and ${ }^{\star *}<0.01$.

In the presence of the luteal phase deficiency, hyperestrogenism, progesterone insufficiency and high levels of testosterone were observed.

Against the background of anovulatory menstrual cycle, an increased excretion of prolactin, within acceptable limits, was observed, as well as a high concentration of testosterone (Table 4).

Table 4. The specifics of the endocrine status in patients with luteal phase deficiency

\begin{tabular}{|l|c|c|c|}
\hline \multirow{2}{*}{ Characteristics } & \multicolumn{3}{|c|}{ Groups of patients } \\
\cline { 2 - 4 } & $\mathbf{1} \mathbf{n}=\mathbf{3 0}$ & $\mathbf{2} \mathbf{n}=\mathbf{1 3}$ & $3 \mathbf{n}=40$ \\
\hline LH $(\mathrm{nmol} / \mathrm{l})$ & $4.65 \pm 0.53$ & $4.25 \pm 0.53$ & $2.75 \pm 0.08$ \\
\hline FSH $(\mathrm{nmol} / \mathrm{l})$ & $4.60 \pm 0.56$ & $2.78 \pm 0.63$ & $3.63 \pm 0.06$ \\
\hline Estradiol $(\mathrm{pg} / \mathrm{ml})$ & $221.12 \pm 46.39$ & $198.92 \pm 20.66$ & $82.56 \pm 18.24$ \\
\hline Progesterone $(\mathrm{nmol} / \mathrm{l})$ & $7.60 \pm 0.84$ & $16.24 \pm 2.22$ & $1.35 \pm 0.08$ \\
\hline Prolactin $(\mathrm{ng} / \mathrm{ml})$ & $7.33 \pm 0.02$ & $17.00 \pm 1.65$ & $4.95 \pm 0.81$ \\
\hline Cortisol $(\mathrm{nmol} / \mathrm{l})$ & $422.09 \pm 45.65$ & $534.72 \pm 25.37$ & $386.254 \pm 33.49$ \\
\hline Testosterone $(\mathrm{ng} / \mathrm{ml})$ & $0.95 \pm 0.29$ & $0.37 \pm 0.02$ & $1.42 \pm 0.32$ \\
\hline
\end{tabular}

Preliability relative to group $3^{*}<0.05$ and ${ }^{*}<0.01$.

Patients with luteal phase insufficiency typically had hyperprolactinemia and estradiol concentration at the upper limit of the normal range. Patients with proliferative fibrocystic disease of the breast and anovulatory menstrual cycle typically had hyperprolactinemia, an increase in the concentration of luteinizing hormone and follicle stimulating hormone with the predominance of the latter, low concentrations of progesterone and estradiol (Table 5).

\section{Conclusions}

The results show that a significant risk factor for hyperplastic processes of the mammary glands and uterus in cases with regular ovulatory menstrual cycle is a decrease in the excretion of progesterone and cortisol, as well as an increase in the concentration of testosterone. 
Table 5. The specifics of endocrinological status in patients with anovulatory menstrual cycle

\begin{tabular}{|l|c|c|}
\hline \multirow{2}{*}{\multicolumn{1}{|c|}{ Characteristics }} & \multicolumn{2}{|c|}{ Groups of patients } \\
\cline { 2 - 3 } & $\mathbf{1 ~ n = 7 0}$ & $2 \mathbf{n}=37$ \\
\hline LH $(\mathrm{nmol} / \mathrm{l})$ & $9.98 \pm 0.29^{*}$ & $16.21 \pm 0.52$ \\
\hline FSH $(\mathrm{nmol} / \mathrm{l})$ & $4.71 \pm 0.59^{* *}$ & $21.88 \pm 4.04$ \\
\hline Estradiol $(\mathrm{pg} / \mathrm{ml})$ & $186.08 \pm 29.31^{* *}$ & $46.95 \pm 13.01$ \\
\hline Progesterone $(\mathrm{nmol} / \mathrm{l})$ & $4.04 \pm 0.07^{* *}$ & $1.13 \pm 0.089$ \\
\hline Prolactin $(\mathrm{ng} / \mathrm{ml})$ & $9.85 \pm 0.36^{*}$ & $5.21 \pm 0.21$ \\
\hline Cortisol $(\mathrm{nmol} / \mathrm{l})$ & $469.25 \pm 32.61^{*}$ & $393.44 \pm 7.92$ \\
\hline Testosterone $(\mathrm{ng} / \mathrm{ml})$ & $1.01 \pm 0.11^{*}$ & $0.78 \pm 0.05$ \\
\hline
\end{tabular}

Against the background of menstrual cycle disorders in the form of luteal phase insufficiency, the risk factor is an increase in the concentration of estradiol in the context of progesterone insufficiency and testosterone hyperproduction. A risk factor for proliferative fibrocystic disease of the breast is hyperprolactinemia in the presence of hyperestrogenism. A risk factor for hyperplastic processes of the mammary glands and uterus in cases of anovulatory menstrual cycle is hyperprolactinemia in the presence of testosterone hyperproduction. A risk factor for proliferative fibrocystic disease of the breast is hyperprolactinemia with an increase in the concentration of follicle stimulating hormone against the background of hypestrogenism and progesterone insufficiency.

\section{References}

1. Breast medicine and gynecological diseases, pod red. V.E. Radzinskogo. $2^{\text {nd }}$ ed., rev. and exp. Rus. Ed. Moscow, StatusPraesens Publ., 2017. 352 p. (In Russian)

2. Silaeva E. A., Shmidt A. A., Gajvoronskih D. I., Timoshkova Yu. L., Anashkina R. I., Atayanc K. M., Varfolomeev D. I. Benign dysplasia of the mammary glands. Modern aspects of the clinic, diagnosis and treatment: A practical guide for physicians. Rus. ed. St. Petersburg, SpecLit Publ., 2018. 78 p. (In Russian)

3. Adamyan L. V., Andreeva E. N., Artymuk N. V., Belocerkovceva L. D., Bezhenar' V. F., Gevorkyan M. A., Gluhov E. Yu., Gus A. I., Dobrohotova Yu. E., Zhordania K. I., Zajrat'yanc O. V., Kozachenko A. V., Kiselev S. I., Kogan E. A., Kuznecova I. V., Kurashvili Yu. B., Levakov S. A., Malyshkina A. I., Mal'ceva L. I., Marchenko L. A., Murvatov K. D., Pestrikova T. Yu., Popov A. A., Protopopova N. V., Samojlova A. V., Sonova M. M., Tihomirov A.L., Tkachenko L.V., Urumova L.T., Filippov O.S., Hashukoeva A.Z., Chernuha G. E., Yarmolinskaya M. I., Yarockaya E. L. Uterine myoma: diagnosis, treatment and rehabilitation. Clinical guidelines for management. Rus. ed. Moscow, Nauchnyj centr akusherstva, ginekologii i perinatologii im. V.I. Kulakova Publ., 2015. 100 p. (In Russian)

4. Shelygin M.S. Combinated benign pathology of the uterus and mammary glands at women of reproductive age: diagnostics and treatment tactics. Zdorove zhenshchiny, 2014, no. 9 (95), p. 158. (In Russian)

5. Novikova V.A. Risk factors for breast cancer in reproductive age. Akusherstvo i ginekologiya, 2015, no. 10, pp. 27-34. (In Russian)

6. Kravchenko E. N., Ozherel'eva M. A. The condition of the mammary glands in gynecological diseases (literature review). Mat' i ditya $v$ Kuzbasse, 2014, no. 2, pp. 19-23. (In Russian)

7. Popov E. N., Ajvazyan T. A., Aleksandrova L. A., Sudakov D. S., Vorob'eva D. D. Evaluation of functional morphology of myometrium in women of reproductive age with combined proliferative diseases 
of the uterus and isolated uterine leiomyoma. Eastern European Scientific Journal, 2016, vol. 1, no. 5, pp. 117-123.

8. Hamoshina M. B., Parenkova I. A. Not to ignore mastopathy - not to allow cancer. A new vector of tactics for mastopathy: active cancer prevention: Informational letter, eds V. E. Radzinskiy, N. I. Rozhkova. Rus. ed. Moscow, StatusPraesens Publ., 2015. 24 p. (In Russian)

9. Vysockaya I. V., Letyagin V.P., Cherenkov V.G., Laktionov K.P., Bublikov I. D. Clinical guidelines of the Russian society of oncomammologists for the prevention of breast cancer, differential diagnosis, treatment of precancerous and benign breast diseases. Opukholi zhenskoj reproduktivnoj sistemy, 2016, vol. 12, no. 3, pp. 43-52. (In Russian)

10. Akhtamova D. A. Optimization of the management of pregnant women with uterine myoma in the second trimester of pregnancy: dissertation. Rus. ed. Samarkand, 2015. 87 p. (In Russian)

11. A national gynecology guide, eds G. M. Savelyeva, G. T. Sukhikh, V. N. Serova et al. $2^{\text {nd }}$ ed., rev. and exp. Moscow, GEOTAR-Media Publ., 2017. 1008 p. National guides. (In Russian)

12. Collins L. C., Aroner S. A., Connolly J. L., Colditz G. A., Schnitt S. J., Tamimi R. M. Breast cancer risk by extent and type of atypical hyperplasia: An update from the Nurses' Health Studies. Cancer, 2016, vol. 122 , no. 4, pp. 515-520.

13. Bespalov V.G., Travina M.L. Fibrocystic disease and breast cancer risk (a review of literature). Opukholi zhenskoj reproduktivnoj sistemy, 2015, vol. 11, no. 4, pp. 58-70. (In Russian)

14. Semiglazov V. F., Semiglazov V. V. Breast cancer: biology, local and systemic treatment. Rus. ed. Moscow, SIMK Publ., 2014. 352 p. (In Russian)

15. Cuzick J., Sestak I., Thorat M. A. Impact of preventive therapy on the risk of breast cancer among women with benign breast disease. Breast, 2015, vol. 24, suppl. 2, pp. S51-S55.

16. Kataria K., Dhar A., Srivastava A., Kumar S., Goyal A. A systematic review of current understanding and management of mastalgia. Indian J. Surg., 2014, vol. 76, no. 3, pp. 217-222.

17. Cuzick J., Sestak I., Forbes J.F., Dowsett M., Knox J., Cawthorn S., Saunders C., Roche N., Mansel R. E., von Minckwitz G., Bonanni B., Palva T., Howell A. Anastrozole for prevention of breast cancer in highrisk postmenopausal women (IBIS-II): an international, double-blind, randomised placebo-controlled trial. Lancet, 2014, vol. 383, no. 9922, pp. 1041-1048.

18. Bilal I., Chowdhury A., Davidson J., Whitehead S. Phytoestrogens and prevention of breast cancer: The contentious debate. World J. Clin. Oncol., 2014, vol. 5, no. 4, pp. 705-712.

19. The state of cancer care to the population of Russia in 2016, eds A. D. Kaprin, V. V. Starinskiy, G. V. Petrova. Moscow, MNIOI im. P. A. Gercena - filial NMICR Minzdrava Russia Publ., 2017. 236 p. (In Russian)

20. Guide to outpatient-polyclinic care in obstetrics and gynecology, eds V. N. Serova, G. T. Sukhikh, V. N. Prilepskaya, V.E. Radzinskiy. $3^{\text {rd }}$ ed., rev. and exp. Moscow, GEOTAR-Media Publ., 2016. 1136 p. (In Russian)

Received: April 20, 2019

Accepted: June 17, 2019

Authors'information:

Mikhail S. Shelygin — Associate Professor, MD; nilamed@mail.ru

Nadezhda S.Guziy — student; guzi1996@yandex.ru

Viktoria S. Kaplitskaya — student; v.kaplitskaya@gmail.com 